\title{
Preparation of Single-phase High Entropy Carbides by a Modified Citric Acid Complexing Method
}

\section{Hu-Lin Liu ( $\nabla$ liuhulin@sust.edu.cn )}

Shaanxi University of Science and Technology Xi'an Campus: Shaanxi University of Science and

Technology https://orcid.org/0000-0002-2393-1751

\section{Feng-Zhen DANG}

Shaanxi University of Science and Technology

\section{De-Wei NI}

Shanghai Institute of Ceramics Chinese Academy of Sciences

\section{Chang-Qing LIU}

Shaanxi University of Science and Technology

\section{Yun-Long XUE}

Shaanxi University of Science and Technology

\section{Yuan-Ting WU}

Shaanxi University of Science and Technology

\section{Research Article}

Keywords: high囚entropy metal carbides, microstructure, composition, sol-gel method

Posted Date: May 20th, 2021

DOI: https://doi.org/10.21203/rs.3.rs-535519/v1

License: (c) (1) This work is licensed under a Creative Commons Attribution 4.0 International License.

Read Full License 


\title{
Preparation of single-phase high entropy carbides by a modified citric acid complexing method
}

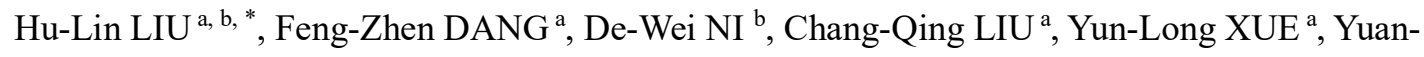 \\ Ting $\mathrm{WU}^{\mathrm{a}}$ \\ a School of Materials Science and Engineering, Shaanxi Key Laboratory of Green Preparation and \\ Functionalization for Inorganic Materials, Shaanxi University of Science \& Technology, Xi'an \\ 710021, China \\ ${ }^{b}$ State Key Laboratory of High Performance Ceramics and Superfine Microstructure, Shanghai \\ Institute of Ceramics, Shanghai 200050, China \\ * Corresponding author. e-mail: liuhulin@sust.edu.cn
}


Abstract: We developed a new method to synthesize single-phase transition metal carbide powders by combining citric acid complexing method and ball-milling dispersion. High-entropy carbides $\quad\left(\mathrm{Zr}_{0.25} \mathrm{Ti}_{0.25} \mathrm{Ta}_{0.25} \mathrm{Nb}_{0.25}\right) \mathrm{C} \quad(4 \mathrm{TmC})$, $\left(\mathrm{Zr}_{0.2} \mathrm{Ti}_{0.2} \mathrm{Ta}_{0.2} \mathrm{Nb}_{0.2} \mathrm{Hf}_{0.2}\right) \mathrm{C}(5 \mathrm{TmC}-\mathrm{H})$ and $\left(\mathrm{Zr}_{0.2} \mathrm{Ti}_{0.2} \mathrm{Ta}_{0.2} \mathrm{Nb}_{0.2} \mathrm{Mo}_{0.2}\right) \mathrm{C}(5 \mathrm{TmC}-\mathrm{M})$ were successfully fabricated by this method using low-cost raw materials. The element and phase composition and microstructures of the obtained carbide powders were investigated. The relationships of synthesis process and temperature with chemical composition were also discussed. $\left(\mathrm{Zr}_{0.25} \mathrm{Ti}_{0.25} \mathrm{Ta}_{0.25} \mathrm{Nb}_{0.25}\right) \mathrm{C}$ can be obtained by a onestep process at $1550{ }^{\circ} \mathrm{C}$, while $\quad\left(\mathrm{Zr}_{0.2} \mathrm{Ti}_{0.2} \mathrm{Ta}_{0.2} \mathrm{Nb}_{0.2} \mathrm{Hf}_{0.2}\right) \mathrm{C}$ and $\left(\mathrm{Zr}_{0.2} \mathrm{Ti}_{0.2} \mathrm{Ta}_{0.2} \mathrm{Nb}_{0.2} \mathrm{Mo}_{0.2}\right) \mathrm{C}$ are fabricated by a two-step process of carbothermal reduction followed by solid solution at the temperatures not lower than $1850{ }^{\circ} \mathrm{C}$ and $1650{ }^{\circ} \mathrm{C}$. The higher synthesis temperatures of the five-component carbides are attributed to the obvious sluggish diffusion effect induced by the larger lattice distortions. The particle sizes of $\left(\mathrm{Zr}_{0.25} \mathrm{Ti}_{0.25} \mathrm{Ta}_{0.25} \mathrm{Nb}_{0.25}\right) \mathrm{C},\left(\mathrm{Zr}_{0.2} \mathrm{Ti}_{0.2} \mathrm{Ta}_{0.2} \mathrm{Nb}_{0.2} \mathrm{Hf}_{0.2}\right) \mathrm{C}$ and $\left(\mathrm{Zr}_{0.2} \mathrm{Ti}_{0.2} \mathrm{Ta}_{0.2} \mathrm{Nb}_{0.2} \mathrm{Mo}_{0.2}\right) \mathrm{C}$ powders are $118.2 \pm 26.1 \mathrm{~nm}$ (at $\left.1550{ }^{\circ} \mathrm{C}\right), 284.8 \pm 73.7$ $\mathrm{nm}\left(\right.$ at $\left.1850{ }^{\circ} \mathrm{C}\right)$ and $65.5 \pm 13.9 \mathrm{~nm}\left(\right.$ at $\left.1750{ }^{\circ} \mathrm{C}\right)$, respectively.

Keywords: high-entropy metal carbides; microstructure; composition; sol-gel method

\section{Introduction}

High entropy ceramics are multi-principal component solid solution materials in which the molar amounts of metal elements at the same lattice sites are equal or near equal, including carbides [1-4], borides [5-8], oxides [9-13], silicides [14, 15], nitrides [16-18] and fluorides [19], etc. High entropy carbides (HEC) have become new candidates of ultra-high temperature ceramics used as structural components in aerospace propulsion and nuclear reactor systems, due to the excellent properties such as high hardness [20, 21], low thermal conductivity [22-24], better oxidation resistance [25, 26], excellent electrical conductivity [27] and so on.

In recent years, several high entropy carbide powders have been successfully synthesized by solid-phase methods and liquid-phase methods [28-34]. Zhou et al. [28] synthesized high-entropy carbide powders $\left(\mathrm{Ti}_{0.2} \mathrm{Zr}_{0.2} \mathrm{Hf}_{0.2} \mathrm{Nb}_{0.2} \mathrm{Ta}_{0.2}\right) \mathrm{C}$ by spark plasma sintering via solid solution reaction between the single-component carbide powders. 
The synthesis temperature is as high as $1950{ }^{\circ} \mathrm{C}$ and the obtained powders have relatively large particle size of approximately $2 \mu \mathrm{m}$. Moskovskikh et al. [29] fabricated high-entropy carbide $\left(\mathrm{Hf}_{0.2} \mathrm{Ta}_{0.2} \mathrm{Ti}_{0.2} \mathrm{Nb}_{0.2} \mathrm{Zr}_{0.2}\right) \mathrm{C}$ through reactive high-energy ball milling of metal and graphite powders. Although this method is simple and efficient, it is easy to introduce impurities such as oxygen and Fe elements in the synthesis process. Liu et al. [30] synthesized high-entropy carbide $\left(\mathrm{Nb}_{0.25} \mathrm{Ta}_{0.25} \mathrm{Mo}_{0.25} \mathrm{~W}_{0.25}\right) \mathrm{C}$ via the direct reaction between metallic powders and graphite. The synthesis temperature is as low as $1800{ }^{\circ} \mathrm{C}$ but the obtained powders have relatively large particle size of $9.0 \pm 0.5$ $\mu \mathrm{m}$. Ye et al. [31] successfully fabricated $\left(\mathrm{Zr}_{0.25} \mathrm{Ta}_{0.25} \mathrm{Nb}_{0.25} \mathrm{Ti}_{0.25}\right) \mathrm{C}$ with the particle size of 0.5-2 $\mu \mathrm{m}$ via one-step carbothermal reduction between the oxides and graphite powders at $2200^{\circ} \mathrm{C}$. Feng et al. [32] also prepared $\left(\mathrm{Hf}_{0.2} \mathrm{Zr}_{0.2} \mathrm{Ti}_{0.2} \mathrm{Ta}_{0.2} \mathrm{Nb}_{0.2}\right) \mathrm{C}$ via a twostep synthesis process consisting of carbothermal reduction at $1600{ }^{\circ} \mathrm{C}$ followed by solid solution reaction at $2000{ }^{\circ} \mathrm{C}$. The synthesis temperatures are also high which are influenced by the activities and particle sizes of the oxide and graphite powders.

Compared with solid-phase methods, the major advantage of liquid-phase method is that the starting reagents can be mixed homogeneously at molecular level in a liquid state. Therefore, the synthesis temperature of the powders is lower and the obtained powders have smaller particle sizes. Li et al. [33] successfully prepared high-entropy $\left(\mathrm{Ti}_{0.2} \mathrm{Zr}_{0.2} \mathrm{Hf}_{0.2} \mathrm{Nb}_{0.2} \mathrm{Ta}_{0.2}\right) \mathrm{C}$ via liquid precursor approach using transition metal halides and furfuryl alcohol as metal sources and carbon source. The precursor is converted into a carbide mixture via carbothermal reduction at a lower temperature of $1400{ }^{\circ} \mathrm{C}$. After the following solid solution reaction at $2000^{\circ} \mathrm{C}$, the obtained single-phase carbide powders are much finer than these derived from solid-phase methods with an average particle of $132 \pm 5 \mathrm{~nm}$. However, some of the used transition metal halides, such as $\mathrm{HfCl}_{4}$ and $\mathrm{TaCl}_{5}$, are expensive, which increases the synthesis cost. Du et al. [34] synthesized $\left(\mathrm{Hf}_{0.25} \mathrm{Nb}_{0.25} \mathrm{Zr}_{0.25} \mathrm{Ti}_{0.25}\right) \mathrm{C}$ via polymer-derived ceramic route at $2200{ }^{\circ} \mathrm{C}$ using transition metal halides and acetylmethane as metal sources and carbon source. The high-entropy carbide consisted of numerous superfine particles with the average particle size of 800 nm. But the used acetylmethane is poisonous. Sun et al. [35] prepared high entropy carbide powder $\left(\mathrm{Ti}_{0.2} \mathrm{Zr}_{0.2} \mathrm{Hf}_{0.2} \mathrm{Ta}_{0.2} \mathrm{Nb}_{0.2}\right) \mathrm{C}$ via liquid polymer precursor route using 
metal alkoxides and allyl-functional novolac resin as metal sources and carbon source. The single-phase carbide powders with average crystalline size of $63 \pm 6 \mathrm{~nm}$ are obtained at $1800{ }^{\circ} \mathrm{C}$. However, the expensive metal halides, such as $\mathrm{HfCl}_{4}, \mathrm{NbCl}_{5}$ and $\mathrm{TaCl}_{5}$, were also used to fabricate the corresponding metal alkoxides. Thus, a new low-cost method should be developed to synthesize superfine high entropy carbide powders at lower temperatures.

In this study, we will synthesize $\left(\mathrm{Ti}_{0.25} \mathrm{Zr}_{0.25} \mathrm{Nb}_{0.25} \mathrm{Ta}_{0.25}\right) \mathrm{C} \quad$ (4TmC), $\left(\mathrm{Ti}_{0.2} \mathrm{Zr}_{0.2} \mathrm{Nb}_{0.2} \mathrm{Ta}_{0.2} \mathrm{Hf}_{0.2}\right) \mathrm{C} \quad(5 \mathrm{TmC}-\mathrm{H})$ and $\left(\mathrm{Ti}_{0.2} \mathrm{Zr}_{0.2} \mathrm{Nb}_{0.2} \mathrm{Ta}_{0.2} \mathrm{Mo}_{0.2}\right) \mathrm{C}$ (5TmC-M) high-entropy carbide powders by combining citric acid complexing method and ballmilling dispersion, using low-cost raw materials. The element and phase composition and microstructures of the as-synthesized powders will be investigated. The relationships between the synthesis temperatures and chemical composition will also be discussed.

\section{Materials and method}

Inorganic metal salts such as zirconium oxychloride $\left(\mathrm{ZrOCl}_{2} \cdot 8 \mathrm{H}_{2} \mathrm{O}, 99.9 \%\right.$, Shanghai Macklin Biochemical Co., Ltd., Shanghai, China), titanium sulfate (Ti( $\left(\mathrm{SO}_{4}\right)_{2}, 96.0 \%$, Sinopharm Chemical Reagent Co., Ltd., Shanghai, China) and ammonium molybdate $\left(\left(\mathrm{NH}_{4}\right)_{6} \mathrm{Mo}_{7} \mathrm{O}_{24} \cdot 4 \mathrm{H}_{2} \mathrm{O}, 99.0 \%\right.$, Tianjin Kermel Laboratory Equipment Co., Ltd., Tianjin, China) were used as zirconium, titanium and molybdenum sources. Oxide powders such as $\mathrm{HfO}_{2}(200 \mathrm{~nm}, 99.9 \%), \mathrm{Nb}_{2} \mathrm{O}_{5}(100 \mathrm{~nm}, 99.9 \%)$ and $\mathrm{Ta}_{2} \mathrm{O}_{5}(0.8 \mathrm{um}, 99.9 \%)$ were used as hafnium, niobium and tantalum sources instead of the corresponding metal salts in order to reduce the cost, which are purchased from Shanghai Puwei Applied Materials Technology Co., Ltd., Shanghai, China. Glucose $\left(\mathrm{C}_{6} \mathrm{H}_{12} \mathrm{O}_{6} \cdot \mathrm{H}_{2} \mathrm{O}\right)$, citric acid (AC) and polyethylene glycol (PEG) were used as carbon source, the complexing agent and dispersant, respectively, purchased from Sinopharm Chemical Reagent Co., Ltd., Shanghai, China. Deionized water was used as the solvent.

Inorganic metal salts were dissolved into deionized water to give out a transparent solution. Then AC, PEG and glucose were added into the transparent solution sequentially. The molar ratio of AC to inorganic metal salts was 1:3 and the mass ratio of AC to PEG was 5:1. The amount of glucose is weighed according to the 
stoichiometric ratio of the metal oxide and carbon in the following chemical reactions from (1) to (6). Ammonia was used to adjust the $\mathrm{pH}$ value of the as-received solution. After being magnetic stirring at room temperature for $6 \mathrm{~h}$, the solution was converted into a translucent sol and metal-citrate chelate complexes were formed in this process. Then oxide powders were added into the sol followed by ball-milling in a polyethylene jar using $\mathrm{ZrO}_{2}$ milling medium balls for $12 \mathrm{~h}$. The well-dispersed suspension was magnetic stirred in a water bath at $70{ }^{\circ} \mathrm{C}$ for 10 hours and a brownish wet gel for HEC was obtained. Finally, the gel was dried in an oven at $80^{\circ} \mathrm{C}$.

$$
\begin{gathered}
\mathrm{ZrO}_{2}+3 \mathrm{C}=\mathrm{ZrC}+\mathrm{CO} \\
\mathrm{TiO}_{2}+3 \mathrm{C}=\mathrm{TiC}+\mathrm{CO} \\
\mathrm{MoO}_{3}+4 \mathrm{C}=\mathrm{MoC}+3 \mathrm{CO} \\
\mathrm{Ta}_{2} \mathrm{O}_{5}+7 \mathrm{C}=2 \mathrm{TaC}+5 \mathrm{CO} \\
\mathrm{Nb}_{2} \mathrm{O}_{5}+7 \mathrm{C}=2 \mathrm{NbC}+5 \mathrm{CO} \\
\mathrm{HfO}_{2}+3 \mathrm{C}=\mathrm{HfC}+\mathrm{CO}
\end{gathered}
$$

The obtained xerogel powders were pressed into disks under a low pressure of 10 $\mathrm{MPa}$ in order to improve particle contact for promoting chemical reaction and solid solution process at high temperatures. The disks were placed in an alumina vacuum tube furnace (GSL-1600X, Hefei Kejing Material Technology Co. Ltd., Hefei, China) and heated to $1550{ }^{\circ} \mathrm{C}$ with the heating rate of $5{ }^{\circ} \mathrm{C} / \mathrm{min}$ in flowing argon atmosphere. Then the furnace was soaked at this temperature for $1.5 \mathrm{~h}$. After heat treatment, the furnace was cooled to $1000{ }^{\circ} \mathrm{C}$ with a cooling rate of $10{ }^{\circ} \mathrm{C} / \mathrm{min}$ followed by naturally cooling. The five-component high entropy carbides, i.e., 5TmC-H and 5TmC-M, were further annealed at the temperature range of $1650-1850{ }^{\circ} \mathrm{C}$ in a graphite resistance furnace element furnace (JDSF/S-1, Shenyang Jinyan New Material Preparation Technology Co., Ltd., Shenyang, China). The heating rate was $10{ }^{\circ} \mathrm{C} / \mathrm{min}$ and the specimens were soaked for $2 \mathrm{~h}$ at the highest temperature. After annealing, the furnace was cooled naturally.

The composition and morphology of the xerogel powders were analyzed by Fourier transform infrared spectroscopy (FT-IR, Vertex70, Burker, Germany) and scanning electron microscopy (SEM, SU8100, Hitachi, Japan). The phase composition of the as- 
synthesized high entropy carbide powders was analyzed by X-ray diffraction (XRD, D/max2200PC, Japan) using $\mathrm{Cu}$ Ka radiation. The XRD patterns of specimens were obtained in the $2 \theta$ range from $20^{\circ}$ to $90^{\circ}$ with a scan speed of $4 \% \mathrm{~min}$. The microstructures and morphology of the products were characterized by SEM equipped with Energy-dispersive X-ray spectroscopy (EDS, Elect Super, TÜV Rheinland, USA) and transmission electron microscopy (TEM, FEI Tecnai G2 F20 S-TWIN, FEI, USA). The particle sizes of the synthesized powders were measured by Nano Measurer software (Version 1.2, Fudan University, China).

\section{Results and Discussion}

\subsection{Characteristics of liquid-phase precursors}

Fig. 1(a) shows the macroscopic characteristics of the as-prepared sol and gel of ZrTi-C liquid-phase precursor. The translucent sol has an obvious Tyndall effect, indicating the uniform mixing of the raw materials. After water bathing, a highviscosity gel was obtained, indicating the formation of a well cross-linked polymer network via the polyesterification between AC and PEG [36]. Similarly, a homogeneous Zr-Ti-Mo-C liquid precursor can be also fabricated by this method. Thus, when the oxide powders such as $\mathrm{Ta}_{2} \mathrm{O}_{5}$ and $\mathrm{Nb}_{2} \mathrm{O}_{5}$ were introduced into the $\mathrm{Zr}$-Ti-C sol, they are dispersed uniformly in the sol after ball-milling and entrapped homogeneously in the polymer network after water-bathing, as shown in Fig. 1(b). Fig. 1(c) exhibits the FT-IR spectrum of the xerogel powders of $4 \mathrm{TmC}$ precursor. The vibrations of $\mathrm{Zr}$ O-C and Ti-O-C bonds are observed at $614 \mathrm{~cm}^{-1}$ and $1102 \mathrm{~cm}^{-1}[37,38]$, indicating the formation of chelating compounds between $\mathrm{Zr}^{4+}, \mathrm{Ti}^{4+}$ and $\mathrm{AC}$. The absorption peaks at $864 \mathrm{~cm}^{-1}$ and $812 \mathrm{~cm}^{-1}$ represent the existence of Ta-O-Ta and $\mathrm{Nb}-\mathrm{O}-\mathrm{Nb}$ bonds $[39,40]$. Fig. $1(d)$ is the SEM image of $4 \mathrm{TmC}$ xerogel powders. The particles have irregular shapes and metal oxides are wrapped by the polymer network. Therefore, all the metallic ions and metal oxide powders are distributed uniformly in the polymer network combing citric acid complexing sol-gel method and ball-milling dispersion, which is beneficial to prompt the reaction and diffusion abilities between the raw materials. 


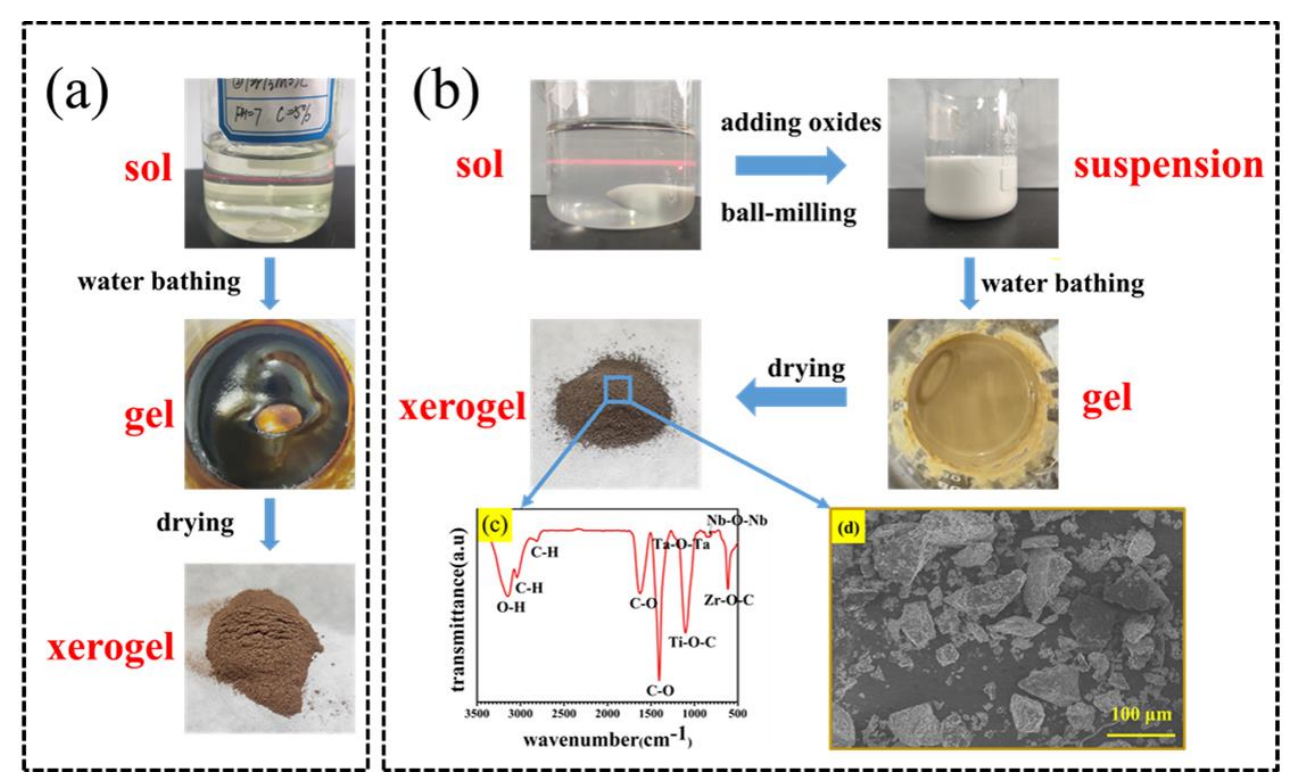

Fig. 1 Schematic illustration for the synthesis procedure of (a) $\mathrm{Zr}$ - $\mathrm{Ti}-\mathrm{C}$ and (b) $\left(\mathrm{Zr}_{0.25} \mathrm{Ti}_{0.25} \mathrm{Ta}_{0.25} \mathrm{Nb}_{0.25}\right) \mathrm{C}$

precursors; (c) FT-IR spectrum and (d) SEM image of as-prepared ( $\left.\mathrm{Zr}_{0.25} \mathrm{Ti}_{0.25} \mathrm{Ta}_{0.25} \mathrm{Nb}_{0.25}\right) \mathrm{C}$ xerogel powders.

\subsection{Microstructure and phase composition of four-component $\left(\mathrm{Zr}_{0.25} \mathrm{Ti}_{0.25} \mathrm{Ta}_{0.25} \mathrm{Nb}_{0.25}\right) \mathrm{C}$}

Fig. 2 shows the XRD patterns of 4 TmC samples with different carbon content heated at $1450{ }^{\circ} \mathrm{C}$ and $1550{ }^{\circ} \mathrm{C}$. $(\mathrm{Ti}, \mathrm{Zr}) \mathrm{O}_{2}$ and $\mathrm{Ta}_{2} \mathrm{C}$ are observed in the samples that excessive carbon content is below 5\% based on the stoichiometry relationships between the reactants. It is attributed to the introduction of excess $\mathrm{ZrO}_{2}$ from milling balls during ball-milling. As a result, the supplied carbon is not sufficient to reducing all the oxides into mono carbides. When carbon content is excessive above 5\%, the XRD peaks of oxides disappear indicating all the metal oxides are converted into carbides. Furthermore, the samples with the excess of $5 \%$ and $10 \%$ carbon exhibit only the peaks of single-phase $\mathrm{NaCl}$ type structure after heat treatment at $1550{ }^{\circ} \mathrm{C}$, whereas the additional peaks exist in the sample annealed at $1450{ }^{\circ} \mathrm{C}$ indicating the presence of a secondary phase. Thus, a single-phase four-component high entropy carbide $4 \mathrm{TmC}$ can be successfully synthesized at $1550{ }^{\circ} \mathrm{C}$ by this method, indicating the one-step completing of the carbothermal reduction reaction and solid solution process. This synthesis temperature is $1550{ }^{\circ} \mathrm{C}$ lower than other similar method reported in references [31], in which $\left(\mathrm{Zr}_{0.25} \mathrm{Ti}_{0.25} \mathrm{Ta}_{0.25} \mathrm{Nb}_{0.25}\right) \mathrm{C}$ was synthesized at $2200{ }^{\circ} \mathrm{C}$ via one-step carbothermal reduction. 


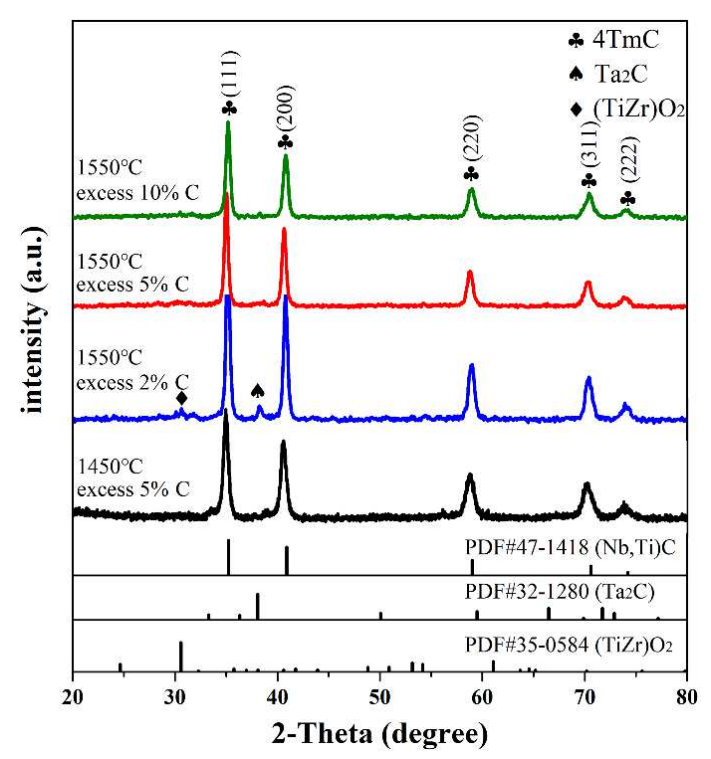

Fig. 2 The XRD patterns of $\left(\mathrm{Zr}_{0.25} \mathrm{Ti}_{0.25} \mathrm{Ta}_{0.25} \mathrm{Nb}_{0.25}\right) \mathrm{C}$ samples with different carbon content heated at $1550{ }^{\circ} \mathrm{C}$ and $1450{ }^{\circ} \mathrm{C}$.

The morphology of the as-synthesized powders with an excess of $5 \%$ at $1550{ }^{\circ} \mathrm{C}$ is analyzed by SEM and TEM, as shown in Fig. 3(a) and (b). The particles are equiaxial with an average size of $118.2 \pm 26.1 \mathrm{~nm}$ measured by SEM and $71.6 \pm 13.3 \mathrm{~nm}$ measured by TEM, which is much smaller than the starting $\mathrm{Ta}_{2} \mathrm{O}_{5}$ powders $(0.8 \mu \mathrm{m})$. This result demonstrates that metal oxides are not the reaction centers during carbothermal reduction and solid solution process. Thus, the small particle size of the obtained powders originates from the high reactivity and homogeneity of the precursors and low synthesis temperature, instead of particle sizes of the starting oxide powders. Moreover, 4TmC powders are agglomerate according to the SEM image, but these agglomeration can be broken up into smaller units after ultrasonic dispersion indicated by the TEM image. Thus, superfine high entropy carbide powders with soft agglomeration could be produced by this method. In Addition, element composition of the synthesized powders was investigated by EDS analysis at the point marked by yellow cross in Fig. 3(a). The molar amounts of the present metal elements are nearly equal to each other, which also indicates the formation of single-phase $\left(\mathrm{Zr}_{0.25} \mathrm{Ti}_{0.25} \mathrm{Ta}_{0.25} \mathrm{Nb}_{0.25}\right) \mathrm{C}$ carbide. 

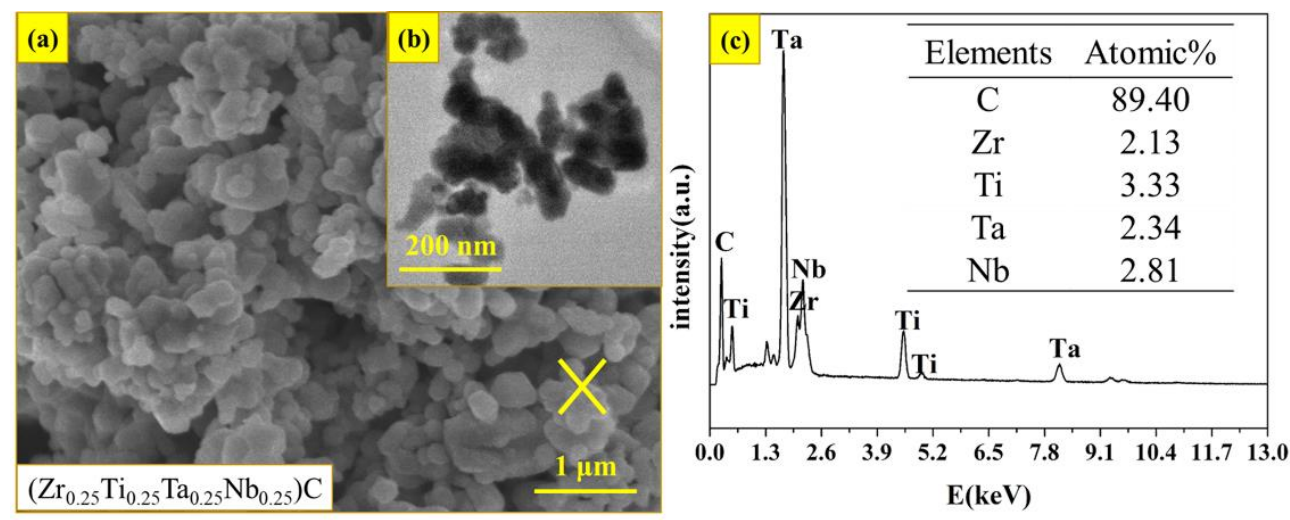

Fig. 3 (a) SEM and (b) TEM images of $\left(\mathrm{Zr}_{0.25} \mathrm{Ti}_{0.25} \mathrm{Ta}_{0.25} \mathrm{Nb}_{0.25}\right) \mathrm{C}$ powders with an excess $5 \% \mathrm{C}$ heated at $1550{ }^{\circ} \mathrm{C}$, and (c) EDS analysis of the region in (a) marked by yellow cross.

3.3 Microstructure and phase composition of five-component $\left(\mathrm{Zr}_{0.2} \mathrm{Ti}_{0.2} \mathrm{Ta}_{0.2} \mathrm{Nb}_{0.2} \mathrm{M}_{0.2}\right) \mathrm{C}$ $(\mathrm{M}=\mathrm{Hf}$ or $\mathrm{Mo})$

Fig. 4 shows the $\mathrm{XRD}$ patterns of $5 \mathrm{TmC}-\mathrm{H}$ after heat treatment at different temperatures. Unlike the four-component high entropy carbide discussed above, two different carbides with $\mathrm{NaCl}$ type structure coexist in the synthesized powders until the annealing temperatures are up to $1850{ }^{\circ} \mathrm{C}$. After heat treated at $1850{ }^{\circ} \mathrm{C}$, these two carbides dissolve into each other accompanied with the formation of a single-phase high entropy carbide $5 \mathrm{TmC}-\mathrm{H}$. Therefore, it is a two-step process that includes the formation of carbides by carbothermal reduction at low temperatures and the solid solution at higher temperature in order to synthesize the single-phase 5TmC-H carbide.

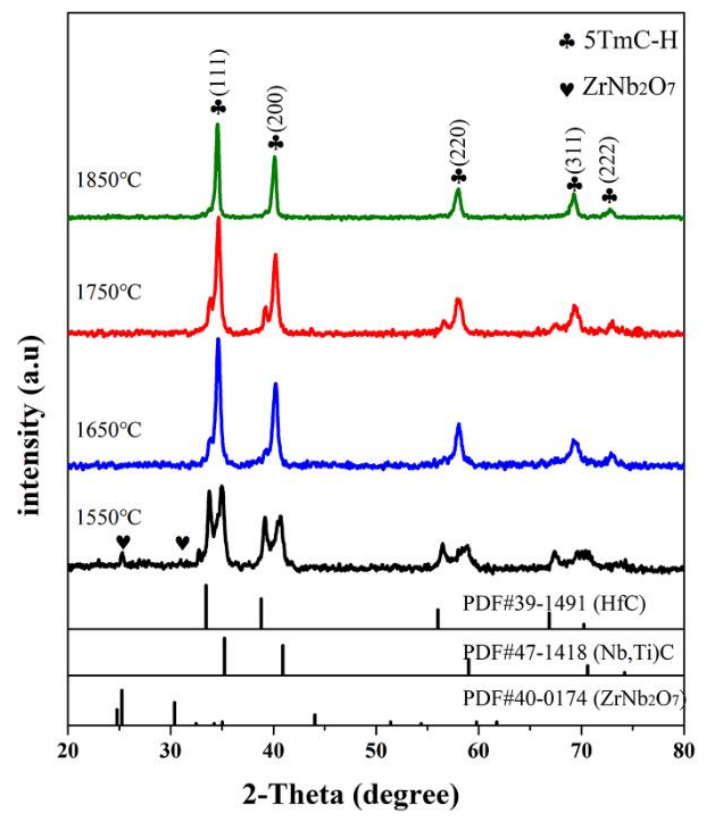

Fig. 4 The XRD patterns of $\left(\mathrm{Zr}_{0.2} \mathrm{Ti}_{0.2} \mathrm{Ta}_{0.2} \mathrm{Nb}_{0.2} \mathrm{Hf}_{0.2}\right) \mathrm{C}$ samples after heat treatment at $1550{ }^{\circ} \mathrm{C}, 1650{ }^{\circ} \mathrm{C}, 1750{ }^{\circ} \mathrm{C}$ 
and $1850{ }^{\circ} \mathrm{C}$, respectively.

Fig. 5 (a) and (b) show the SEM and TEM images of 5TmC-H powders annealed at $1850{ }^{\circ} \mathrm{C}$. The particles are equiaxial with some agglomeration. And the average particle size is $284.8 \pm 73.7 \mathrm{~nm}$ measured by SEM and $204.9 \pm 64.0 \mathrm{~nm}$ measured by TEM. According to the EDS point analysis displayed in Fig. 5 (c), Zr, Ti, Ta, Nb, and $\mathrm{Hf}$ metal elements are detected in the synthesized powders with near equal molar ratio, which is consistent with the composition of these elements in the precursor. This result also reveals that only one kind of high entropy carbide exists in the obtained powders.
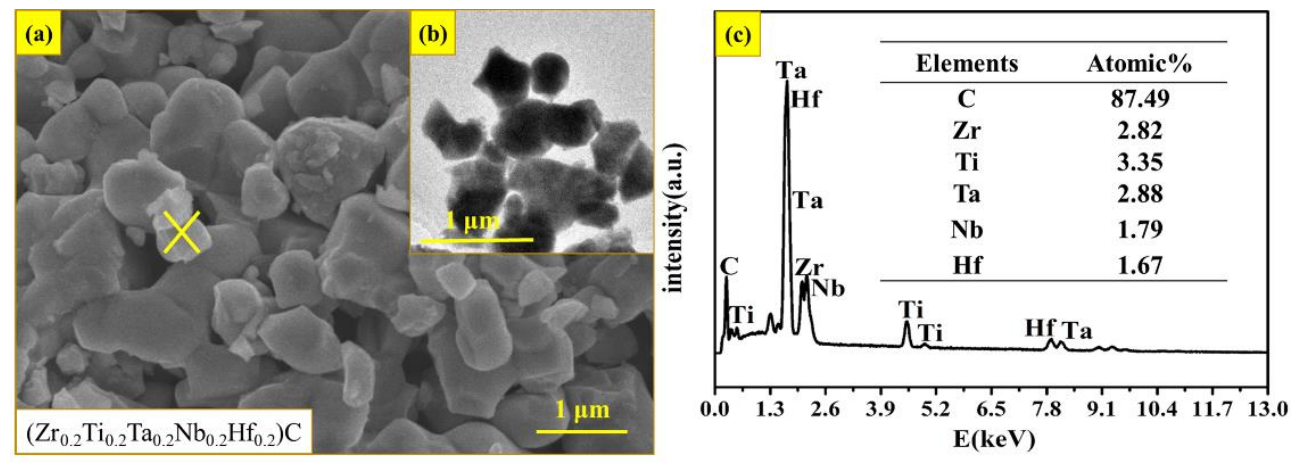

Fig. 5 (a) SEM and (b) TEM images of $\left(\mathrm{Zr}_{0.2} \mathrm{Ti}_{0.2} \mathrm{Ta}_{0.2} \mathrm{Nb}_{0.2} \mathrm{Hf}_{0.2}\right) \mathrm{C}$ powders annealed at $1850{ }^{\circ} \mathrm{C}$, and (b) EDS point analysis of the region in (a) marked by yellow cross.

The synthesis characteristics of $5 \mathrm{TmC}-\mathrm{M}$ powders is similar to that of $5 \mathrm{TmC}-\mathrm{H}$ powders. Based on the XRD analysis, two different carbide phase, namely, a major high entropy monocarbide with $\mathrm{NaCl}$ type structure and a minor $\mathrm{Mo}_{2} \mathrm{C}$ phase, are observed in the products when the precursor is annealed at $1550{ }^{\circ} \mathrm{C}$, as shown in Fig. 6. The diffraction peaks of $\mathrm{Mo}_{2} \mathrm{C}$ phase disappear when the annealing temperature increases to $1650{ }^{\circ} \mathrm{C}$, indicating that $\mathrm{Mo}_{2} \mathrm{C}$ phase dissolves into the monocarbide and a singlephase 5TmC-M solid solution is formed successfully. Thus, the five-component 5TmCM powders are also synthesized via a two-step process of carbothermal reduction followed by high-temperature solid solution. 


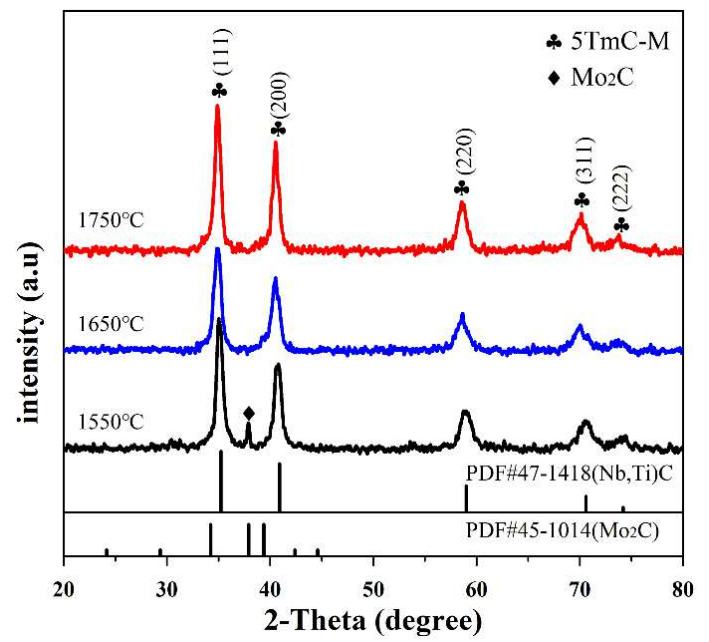

Fig. 6 The XRD patterns of $\left(\mathrm{Zr}_{0.2} \mathrm{Ti}_{0.2} \mathrm{Ta}_{0.2} \mathrm{Nb}_{0.2} \mathrm{Mo}_{0.2}\right) \mathrm{C}$ samples after heat treatment at $1550{ }^{\circ} \mathrm{C}, 1650{ }^{\circ} \mathrm{C}$ and $1750{ }^{\circ} \mathrm{C}$, respectively.

The microstructures of 5TmC-M annealed at $1750{ }^{\circ} \mathrm{C}$ are shown in Fig. 7. The powders are agglomerated and have an average particle size of $65.5 \pm 13.9 \mathrm{~nm}$ according to the SEM image (Fig. 7(a)). All the designed metal elements, i.e., Zr, Ti, Ta, Nb and Hf, are detected in the particles by EDS point analysis and their molar amounts are almost equal to each other, which is described in Fig. 7 (c). This result also verifies the formation of single-phase 5TmC-M solid solution. In addition, TEM result also presents the morphology of the synthesized powders, which have regular polygonal shape with the average size of $31.8 \pm 7.5 \mathrm{~nm}$ as shown in Fig. 7 (b). Thus, the crystal shapes can be well developed with slow grain growth.
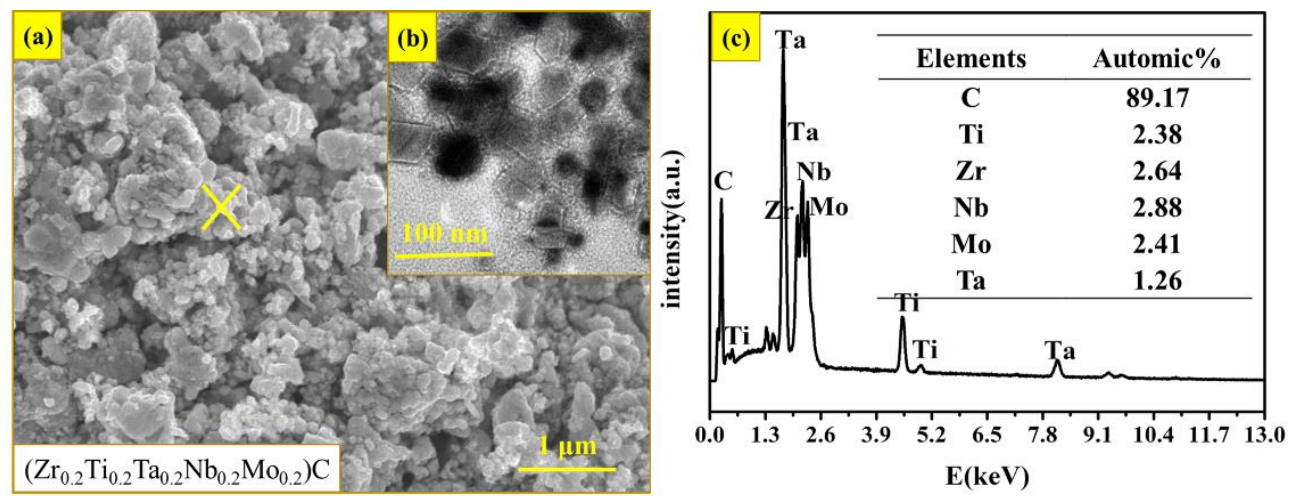

Fig. 7 (a) SEM and (b) TEM images of $\left(\mathrm{Zr}_{0.2} \mathrm{Ti}_{0.2} \mathrm{Ta}_{0.2} \mathrm{Nb}_{0.2} \mathrm{Mo}_{0.2}\right) \mathrm{C}$ powders annealed at $1750{ }^{\circ} \mathrm{C}$, and (c) EDS point analysis of the region in (a) marked by yellow cross.

\subsection{The relationships between element composition and synthesis temperatures of high} entropy carbides 
As discussed above, the synthesis temperatures of different high entropy carbides vary with the chemical composition. The four-component $4 \mathrm{TmC}$ can be obtained at $1550{ }^{\circ} \mathrm{C}$ via a one-step process, while the five-component carbides $5 \mathrm{TmC}-\mathrm{H}$ and 5TmC-M are fabricated by a two-step process with the final temperature at $1850{ }^{\circ} \mathrm{C}$ and $1650{ }^{\circ} \mathrm{C}$, respectively. It can be investigated from the point of view of thermodynamics and kinetics.

During the formation of multi-component carbide via solid solution process between the relevant carbides, the Gibbs free energy change $(\Delta \mathrm{G})$ can be expressed as following equation.

$$
\Delta \mathrm{G}=\Delta \mathrm{H}-\mathrm{T} \Delta \mathrm{S}
$$

Where $\mathrm{T}$ is the temperature, $\Delta \mathrm{H}$ and $\Delta \mathrm{S}$ are the entropy change and enthalpy change, respectively. The multi-component carbide has larger configurational entropy which is beneficial to stabilize the structure at high temperature. However, the enthalpy change of multi-component carbides with different chemical composition will be different, due to the different atomic radius and electronegativity of the metal elements [41]. The differences of atomic radius and electronegativity $\left(\delta\right.$ and $\left.\Delta \chi_{A}\right)$ in the carbides can be assessed as equation (8) and (9) [42-45].

$$
\begin{gathered}
\delta=\sqrt{\sum_{i=1}^{n} c_{i}\left(1-r_{i} / \sum_{j=1}^{n} c_{j} r_{j}\right)^{2}} \\
\Delta \chi_{A}=\sqrt{\sum_{i=1}^{n} c_{i}\left(1-\chi_{i} / \sum_{j=1}^{n} c_{j} \chi_{j}\right)^{2}}
\end{gathered}
$$

Where $c_{i}$ is the molar fraction of the $i$-th metal element, $r_{i}$ and $\chi_{i}$ are atomic radius and Allen electronegativity of the $i$-th metal element which are listed in Table 1 . Thus, the $\delta$ values of $4 \mathrm{TmC}, 5 \mathrm{TmC}-\mathrm{H}$, and $5 \mathrm{TmC}-\mathrm{M}$ are $3.98 \%, 4.26 \%$ and $4.66 \%$, respectively. Larger $\delta$ value represents large lattice distortion which introduces distortion energy in the system [46]. The $\Delta \chi_{A}$ value of $4 \mathrm{TmC}, 5 \mathrm{TmC}-\mathrm{H}$, and $5 \mathrm{TmC}-\mathrm{M}$ are $2.56 \%, 6.57 \%$ and $3.84 \%$, respectively. Larger $\Delta \chi_{A}$ value indicates more different physicochemical properties of the metal elements, resulting in reducing the structure stability of carbide solid solution [47]. Thus, the enthalpy changes of these two five-component carbides will be larger than that of the four-component carbide, which will influence the stability 
of single-phase five-component carbides at low temperatures.

Table 1 The atomic radius and electronegativity of metal elements involved in this study

\begin{tabular}{ccccccc}
\hline Element & $\mathrm{Zr}$ & $\mathrm{Ti}$ & $\mathrm{Hf}$ & $\mathrm{Ta}$ & $\mathrm{Nb}$ & $\mathrm{Mo}$ \\
\hline Atomic radius $(\AA)[48]$ & 1.597 & 1.467 & 1.585 & 1.457 & 1.456 & 1.386 \\
\hline Allen electronegativity [49] & 1.32 & 1.18 & 1.16 & 1.34 & 1.41 & 1.47
\end{tabular}

In order to investigate the structure stability of single-phase 5TmC-H and 5TmC$\mathrm{M}$, we annealed these two carbides at $1550{ }^{\circ} \mathrm{C}$ for $5 \mathrm{~h}$. And their XRD patterns are displayed in Fig. 8. The diffraction peaks of the two samples have no difference with 5TmC-H and 5TmC-M powders synthesized at $1850^{\circ} \mathrm{C}$ and $1650^{\circ} \mathrm{C}$, respectively. This result indicates that these two five-component carbides are still stable at this temperature which is lower than their synthesis temperatures. Thus, the higher synthesis temperatures of the five-component carbides $5 \mathrm{TmC}-\mathrm{H}$ and $5 \mathrm{TmC}-\mathrm{M}$ are attributed to the kinetics characteristics compared with the four-component carbide 4TmC, which can be explained by the sluggish diffusion effect of high entropy materials [12, 24, 26]. The larger lattice distortions of the five-component carbides indicated by the larger $\delta$ and $\Delta \chi_{A}$ impede the atomic diffusion and make the solid solution process slower. As a result, these two five-component carbides need higher annealing temperatures to accelerate the atomic diffusion to form a single-phase structure. In addition, the particle size of $5 \mathrm{TmC}-\mathrm{M}$ synthesized at $1750{ }^{\circ} \mathrm{C}(65.5 \pm 13.9 \mathrm{~nm})$ is much smaller than $4 \mathrm{TmC}$ synthesized at $1550{ }^{\circ} \mathrm{C}(118.2 \pm 26.1 \mathrm{~nm})$ as mentioned above. This phenomenon also demonstrates the more obvious sluggish diffusion effect in five-component carbide than that in four-component carbide.

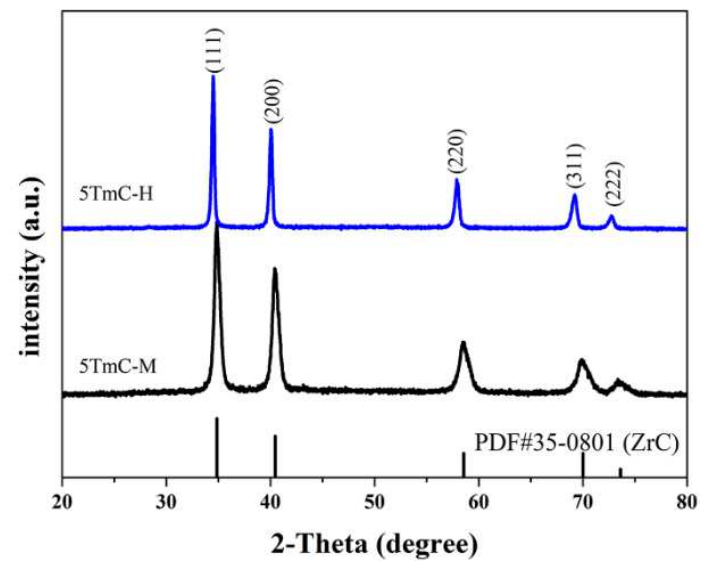


Fig. 8 The XRD of single phase $\left(\mathrm{Zr}_{0.2} \mathrm{Ti}_{0.2} \mathrm{Ta}_{0.2} \mathrm{Nb}_{0.2} \mathrm{Hf}_{0.2}\right) \mathrm{C}$ and $\left(\mathrm{Zr}_{0.2} \mathrm{Ti}_{0.2} \mathrm{Ta}_{0.2} \mathrm{Nb}_{0.2} \mathrm{Mo}_{0.2}\right) \mathrm{C}$ heated treated at $1550{ }^{\circ} \mathrm{C}$ in argon atmosphere for $5 \mathrm{~h}$.

\section{Conclusions}

In this study, we successfully synthesized the superfine single-phase high-entropy $\left(\mathrm{Zr}_{0.25} \mathrm{Ti}_{0.25} \mathrm{Ta}_{0.25} \mathrm{Nb}_{0.25}\right) \mathrm{C},\left(\mathrm{Zr}_{0.2} \mathrm{Ti}_{0.2} \mathrm{Ta}_{0.2} \mathrm{Nb}_{0.2} \mathrm{Hf}_{0.2}\right) \mathrm{C}$ and $\left(\mathrm{Zr}_{0.2} \mathrm{Ti}_{0.2} \mathrm{Ta}_{0.2} \mathrm{Nb}_{0.2} \mathrm{Mo}_{0.2}\right) \mathrm{C}$ carbide powders by combining citric acid complexing method and ball-milling dispersion. $\left(\mathrm{Zr}_{0.25} \mathrm{Ti}_{0.25} \mathrm{Ta}_{0.25} \mathrm{Nb}_{0.25}\right) \mathrm{C}$ can be obtained at $1550{ }^{\circ} \mathrm{C}$ via a one-step process and the average particle size is $118.2 \pm 26.1 \mathrm{~nm}$. However, $\left(\mathrm{Zr}_{0.2} \mathrm{Ti}_{0.2} \mathrm{Ta}_{0.2} \mathrm{Nb}_{0.2} \mathrm{Hf}_{0.2}\right) \mathrm{C}$ and $\left(\mathrm{Zr}_{0.2} \mathrm{Ti}_{0.2} \mathrm{Ta}_{0.2} \mathrm{Nb}_{0.2} \mathrm{Mo}_{0.2}\right) \mathrm{C}$ are fabricated by a two-step process of carbothermal reduction followed by high-temperature solid solution, and the synthesis temperatures at solid solution process are not lower than $1850{ }^{\circ} \mathrm{C}$ and $1650{ }^{\circ} \mathrm{C}$, due to the obvious sluggish diffusion effect induced by the larger lattice distortions. The average particle sizes of $\left(\mathrm{Zr}_{0.2} \mathrm{Ti}_{0.2} \mathrm{Ta}_{0.2} \mathrm{Nb}_{0.2} \mathrm{Hf}_{0.2}\right) \mathrm{C}$ and $\left(\mathrm{Zr}_{0.2} \mathrm{Ti}_{0.2} \mathrm{Ta}_{0.2} \mathrm{Nb}_{0.2} \mathrm{Mo}_{0.2}\right) \mathrm{C}$ powders are $284.8 \pm 73.7 \mathrm{~nm}\left(\right.$ at $1850^{\circ} \mathrm{C}$ ) and $65.5 \pm 13.9 \mathrm{~nm}\left(\right.$ at $1750{ }^{\circ} \mathrm{C}$ ), respectively. This work provides a new synthesis methodology for high-entropy metal carbide powders, which can reduce the synthesis temperature and raw material cost.

\section{Acknowledgments}

Financial supports from the National Natural Science Foundation of China (No. 51702192), the Natural Science Foundation of Shaanxi Province (No. 2019JQ-451), the Opening Project of State Key Laboratory of High Performance Ceramics and Superfine Microstructure (No. SKL201901SIC), and the Special Research Projects of Shaanxi Provincial Department of Education (No. 19JK0144) are gratefully acknowledged.

\section{References}

[1] Zhao Q, Mei J, Jin W, et al. A novel approach to the rapid synthesis of high-entropy carbide nanoparticles. J Am Ceram Soc 2020, 103: 4733-4737.

[2] Chicardi E, García-Garrido C, Hernández-Saz J, et al. Synthesis of all equiatomic fivetransition metals High Entropy Carbides of the IVB (Ti, Zr, Hf) and VB (V, Nb, Ta) groups by a low temperature route. Ceram Int 2020, 46: 21421-21430.

[3] Dusza J, Švec P, Girman V, et al. Microstructure of (Hf-Ta-Zr-Nb)C high-entropy carbide at 
micro and nano/atomic level. J Eur Ceram Soc 2018, 38: 4303-4307.

[4] Zhang Y, Sun SK, Guo WM, et al. Optimal preparation of high-entropy boride-silicon carbide ceramics. J Adv Ceram 2021, 10: 173-180.

[5] Zhang Y, Guo WM, Jiang ZB, et al. Dense high-entropy boride ceramics with ultra-high hardness. Scripta Mater 2019, 164: 135-139.

[6] Qin M, Gild J, Wang $\mathrm{H}$, et al. Dissolving and stabilizing soft $\mathrm{WB}_{2}$ and $\mathrm{MoB}_{2}$ phases into high-entropy borides via boron-metals reactive sintering to attain higher hardness. J Eur Ceram Soc 2020, 40: 4348-4353.

[7] Gild J, Kaufmann K, Vecchio K, et al. Reactive flash spark plasma sintering of high-entropy ultrahigh temperature ceramics. Scripta Mater 2019, 170: 106-110.

[8] Liu JX, Shen XQ, Wu Y, et al. Mechanical properties of hot-pressed high-entropy diboridebased ceramics. J Adv Ceram 2020, 9: 503-510

[9] Pitike KC, Marquez-Rossy AE, Flores-Betancourt A, et al. On the elastic anisotropy of the entropy-stabilized oxide (Mg, Co, Ni, Cu, Zn)O compound. J Appl Phys 2020, 128: 015101.

[10] Wang D, Jiang S, Duan C, et al. Spinel-structured high entropy oxide (FeCoNiCrMn) $)_{3} \mathrm{O}_{4}$ as anode towards superior lithium storage performance. J Alloys Compd 2020, 844: 156158.

[11] Wang G, Qin J, Feng Y, et al. Sol-gel synthesis of spherical mesoporous high-entropy oxides. ACS Appl Mater Inter 2020, 12: 45155-45164.

[12] Zhao ZF, Chen H, Xiang HM, et al. High entropy defective fluorite structured rare-earth niobates and tantalates for thermal barrier applications. J Adv Ceram 2020, 9: 303-311.

[13] Zheng Y, Zou M, Zhang W, et al. Electrical and thermal transport behaviours of high-entropy perovskite thermoelectric oxides. J Adv Ceram 2021, 10: 377-384.

[14] Qin Y, Liu JX, Li F, et al. A high entropy silicide by reactive spark plasma sintering. J Adv Ceram 2019, 8: 148-152.

[15] Liu L, Zhang L, Liu D. Complete elimination of pest oxidation by high entropy refractory metallic silicide $\left(\mathrm{Mo}_{0.2} \mathrm{~W}_{0.2} \mathrm{Cr}_{0.2} \mathrm{Ta}_{0.2} \mathrm{Nb}_{0.2}\right) \mathrm{Si}_{2}$. Scripta Mater 2020, 189: 25-29.

[16] Jin T, Sang X, Unocic RR, et al. Mechanochemical-assisted synthesis of high-entropy metal nitride via a soft urea strategy. Adv Mater 2018, 30: 1707512.

[17] Lin YC, Hsu SY, Song RW, et al. Improving the hardness of high entropy nitride $\left(\mathrm{Cr}_{0.35} \mathrm{Al}_{0.25} \mathrm{Nb}_{0.12} \mathrm{Si}_{0.08} \mathrm{~V}_{0.20}\right) \mathrm{N}$ coatings via tuning substrate temperature and bias for anti- 
wear applications. Surf Coat Technol 2020, 403: 126417.

[18] Pogrebnjak AD, Yakushchenko IV, Bondar OV, et al. Irradiation resistance, microstructure and mechanical properties of nanostructured (TiZrHfVNbTa) N coatings. J Alloys Compd 2016, 679: 155-163.

[19] Wang T, Chen H, Yang Z, et al. High-entropy perovskite fluorides: a new platform for oxygen evolution catalysis. J Am Chem Soc 2020, 142: 4550-4554.

[20] Sarker P, Harrington T, Toher C, et al. High-entropy high-hardness metal carbides discovered by entropy descriptors. Nat Commun 2018, 9: 4980.

[21] Ye BL, Wen TQ, Nguyen MC, et al. First-principles study, fabrication and characterization of $\left(\mathrm{Zr}_{0.25} \mathrm{Nb}_{0.25} \mathrm{Ti}_{0.25} \mathrm{~V}_{0.25}\right) \mathrm{C}$ high-entropy ceramics. Acta Mater 2019, 170: 15-23.

[22] Chen H, Xiang HM, Dai FZ, et al. High porosity and low thermal conductivity high entropy $\left(\mathrm{Zr}_{0.2} \mathrm{Hf}_{0.2} \mathrm{Ti}_{0.2} \mathrm{Nb}_{0.2} \mathrm{Ta}_{0.2}\right)$ C. J Mater Sci Technol 2019, 35: 1700-1705.

[23] Yan X, Constantin L, Lu Y, et al. $\left(\mathrm{Hf}_{0.2} \mathrm{Zr}_{0.2} \mathrm{Ta}_{0.2} \mathrm{Nb}_{0.2} \mathrm{Ti}_{0.2}\right) \mathrm{C}$ high-entropy ceramics with low thermal conductivity. J Am Ceram Soc 2018, 101: 4486-4491.

[24] Li F, Zhou L, Liu JX, et al. High-entropy pyrochlores with low thermal conductivity for thermal barrier coating materials. J Adv Ceram 2019, 8: 576-582.

[25] Yu D, Yin J, Zhang B, et al. Recent development of high-entropy transitional carbides: a review. J Ceram Soc Jpn 2020, 128: 329-335.

[26] Tan Y, Chen C, Li S, et al. Oxidation behaviours of high-entropy transition metal carbides in $1200{ }^{\circ} \mathrm{C}$ water vapor. J Alloys Compd 2020, 816: 152523.

[27] Rost CM, Borman T, Hossain MD, et al. Electron and phonon thermal conductivity in high entropy carbides with variable carbon content. Acta Mater 2020, 196: 231-239.

[28] Zhou J, Zhang J, Zhang F, et al. High-entropy carbide: A novel class of multicomponent ceramics. Ceram Int 2018, 44: 22014-22018.

[29] Moskovskikh DO, Vorotilo S, Sedegov AS, et al. High-entropy (HfTaTiNbZr)C and (HfTaTiNbMo)C carbides fabricated through reactive high-energy ball milling and spark plasma sintering. Ceram Int 2020, 46: 19008-19014.

[30] Liu DQ, Zhang AJ, Jia JG, et al. Reaction synthesis and characterization of a new class high entropy carbide (NbTaMoW)C. Mater Sci Eng A 2021, 804: 140520.

[31] Ye BL, Ning SS, Liu D, et al. One-step synthesis of coral-like high-entropy metal carbide 
powders. J Am Ceram Soc 2019, 102: 6372-6378.

[32] Feng L, Fahrenholtz WG, Hilmas GE, et al. Synthesis of single-phase high-entropy carbide powders. Scripta Mater 2019, 162: 90-93.

[33] Li F, Lu Y, Wang XG, et al. Liquid precursor-derived high-entropy carbide nanopowders. Ceram Int 2019, 45: 22437-22441.

[34] Du B, Liu HH, Chu YH. Fabrication and characterization of polymer-derived high-entropy carbide ceramic powders. J Am Ceram Soc 2020, 103: 4063-4068.

[35] Sun Y, Chen F, Qiu W, et al. Synthesis of rare earth containing single-phase multicomponent metal carbides via liquid polymer precursor route. J Am Ceram Soc 2020, 103: 6081-6087.

[36] Danks AE, Hall SR, Schnepp Z. The evolution of 'sol-gel' chemistry as a technique for materials synthesis. Mater Horizons 2016, 3: 91-112.

[37] Han YT, Liu M, Li KY, et al. Facile synthesis of morphology and size-controlled zirconium metal-organic framework UiO-66: the role of hydrofluoric acid in crystallization. Cryst Eng Comm 2015, 17: 6434-6440.

[38] Balamurugan A, Kannan S, Rajeswari S. Evaluation of $\mathrm{TiO}_{2}$ coatings obtained using the solgel technique on surgical grade type 316L stainless steel in simulated body fluid. Mater Lett 2005, 59: 3138-3143.

[39] Son JH, Casey WH. Titanium-substituted polyoxotantalate clusters exhibiting wide $\mathrm{pH}$ stabilities: $\left[\mathrm{Ti}_{2} \mathrm{Ta}_{8} \mathrm{O}_{28}\right]^{8-}$ and $\left[\mathrm{Ti}_{12} \mathrm{Ta}_{6} \mathrm{O}_{44}\right]^{10-}$. Chem-Eur J 2016, 22: 14155-141157.

[40] Ristić M, Popović S, Musić S. Sol-gel synthesis and characterization of $\mathrm{Nb}_{2} \mathrm{O}_{5}$ powders. Mater Lett 2004, 58: 2658-2663.

[41] Zhang RF, Sheng SH, Liu BX. Predicting the formation enthalpies of binary intermetallic compounds. Chem Phys Lett 2007, 442: 511-514.

[42] Zhang Y, Zhou YJ, Lin JP, et al. Solid-solution phase formation rules for multi-component. Alloys Adv Eng Mater 2008, 10: 534-538.

[43] Zhang Y, Lu ZP, Ma SG, et al. Guidelines in predicting phase formation of high-entropy alloys. MRS Commun 2014, 4: 57-62.

[44] Poletti MG, Fiore G, Szost BA, et al. Search for high entropy alloys in the X-NbTaTiZr systems (X=Al, Cr, V, Sn). J Alloys Compd 2015, 620: 283-288.

[45] Yurchenko N, Stepanov N, Salishchev G. Laves-phase formation criterion for high-entropy 
alloys. Mater Sci Technol 2016, 33: 17-22.

[46] Roy A, Sreeramagiri P, Babuska T, et al. Lattice distortion as an estimator of solid solution strengthening in high-entropy alloys. Mater Charact 2021, 172: 110877.

[47] Zhang Y, Chen X, Jayalakshmi S, et al. Factors determining solid solution phase formation and stability in $\mathrm{CoCrFeNiX} \mathrm{X}_{0.4}(\mathrm{X}=\mathrm{Al}, \mathrm{Nb}, \mathrm{Ta})$ high entropy alloys fabricated by powder plasma arc additive manufacturing. J Alloys Compd 2021, 857: 157625.

[48] Toth LE. Transition Metal Carbides and Nitrides. New York and London: Academic Press, 1971.

[49] Mann J, Meek T, Knight E, et al. Configuration energies of the d-block elements. J Am Chem Soc 2000, 122: 5132-5137. 
Figures

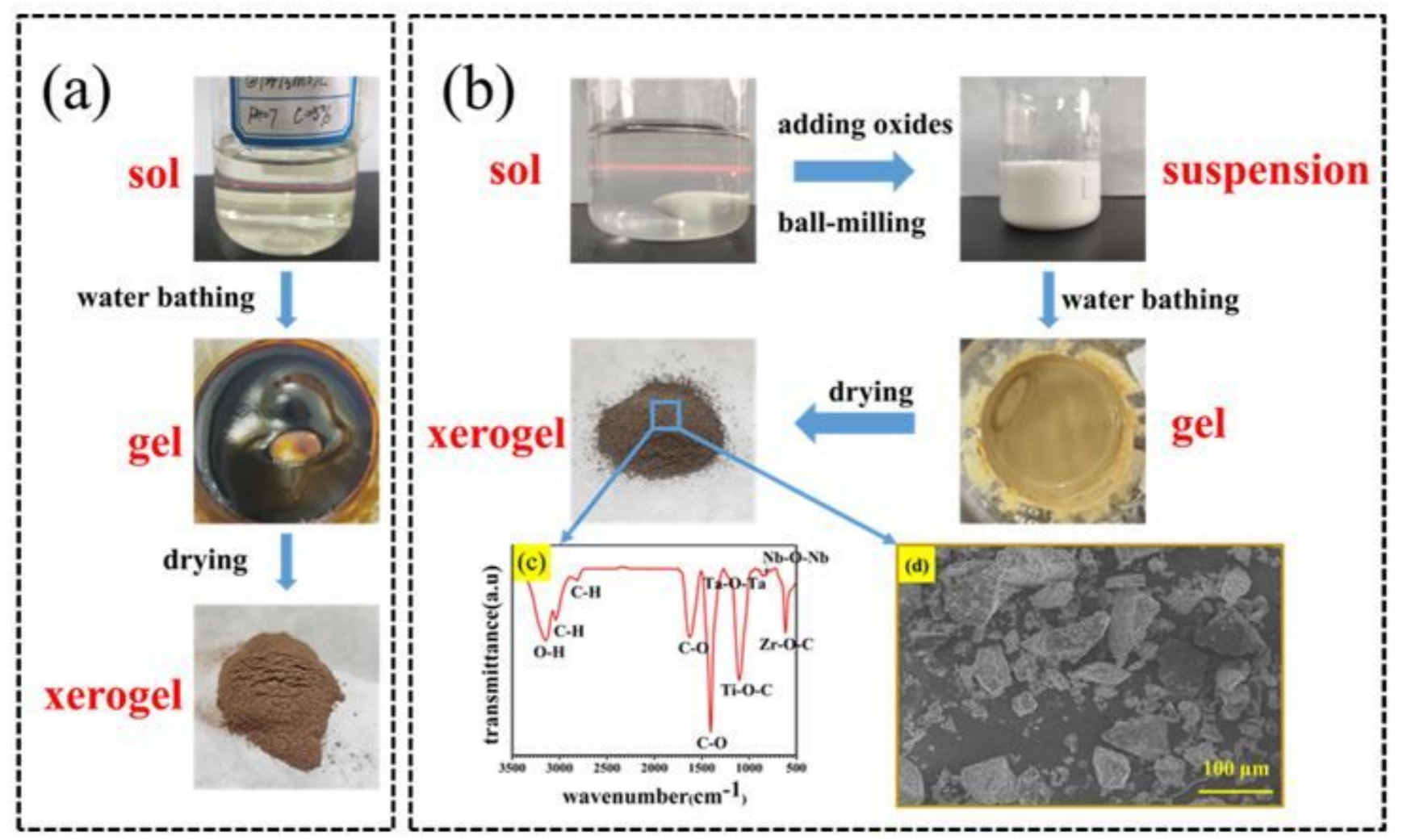

Figure 1

Schematic illustration for the synthesis procedure of (a) Zr-Ti-C and (b) (Zr0.25Ti0.25Ta0.25Nb0.25)C precursors; (c) FT-IR spectrum and (d) SEM image of as-prepared (Zr0.25Ti0.25Ta0.25 Nb0.25)C xerogel powders. 


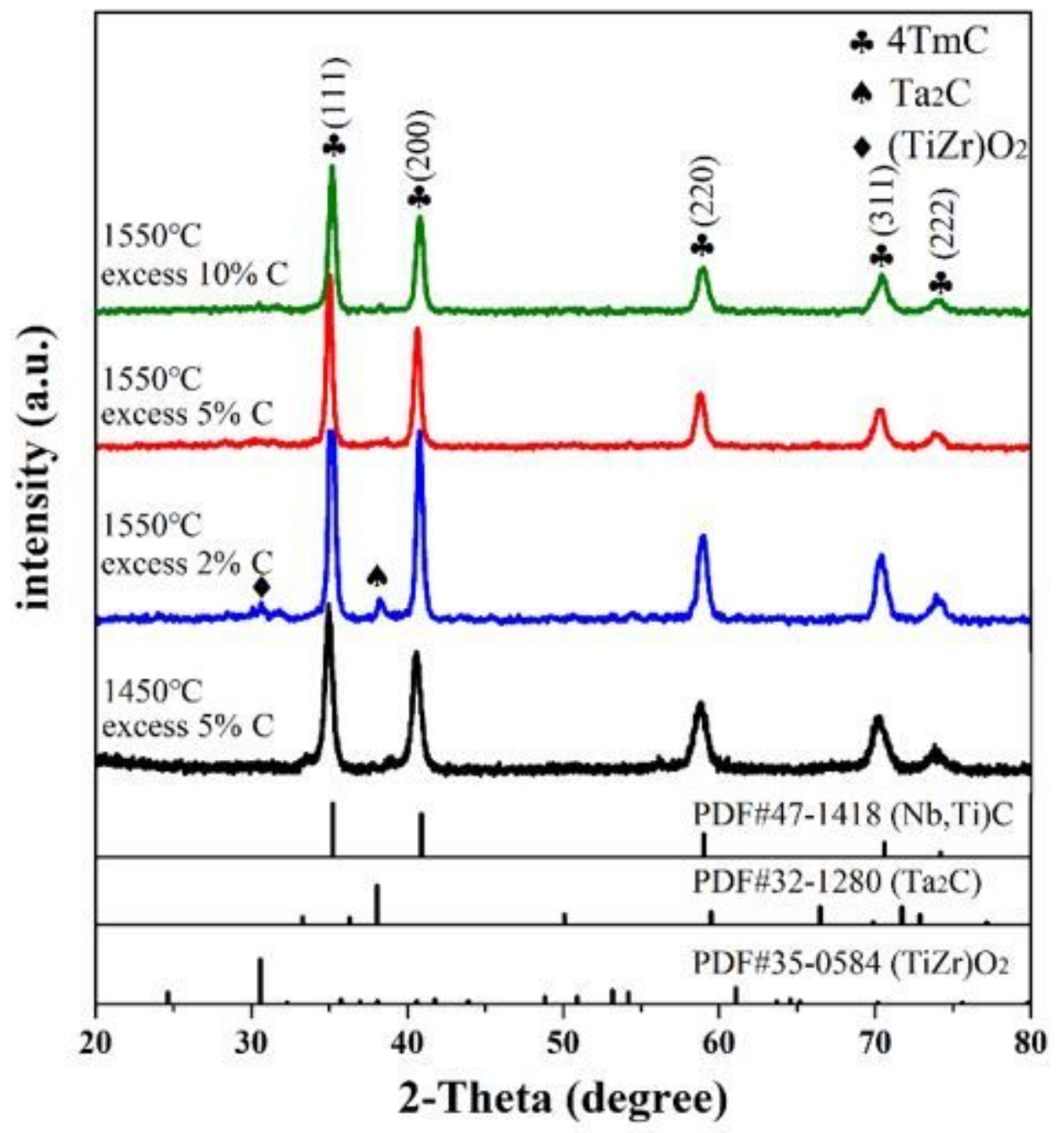

Figure 2

The XRD patterns of (Zr0.25Ti0.25Ta0.25Nb0.25)C samples with different carbon content heated at 1550 $\triangle$ and 1450 ه. 

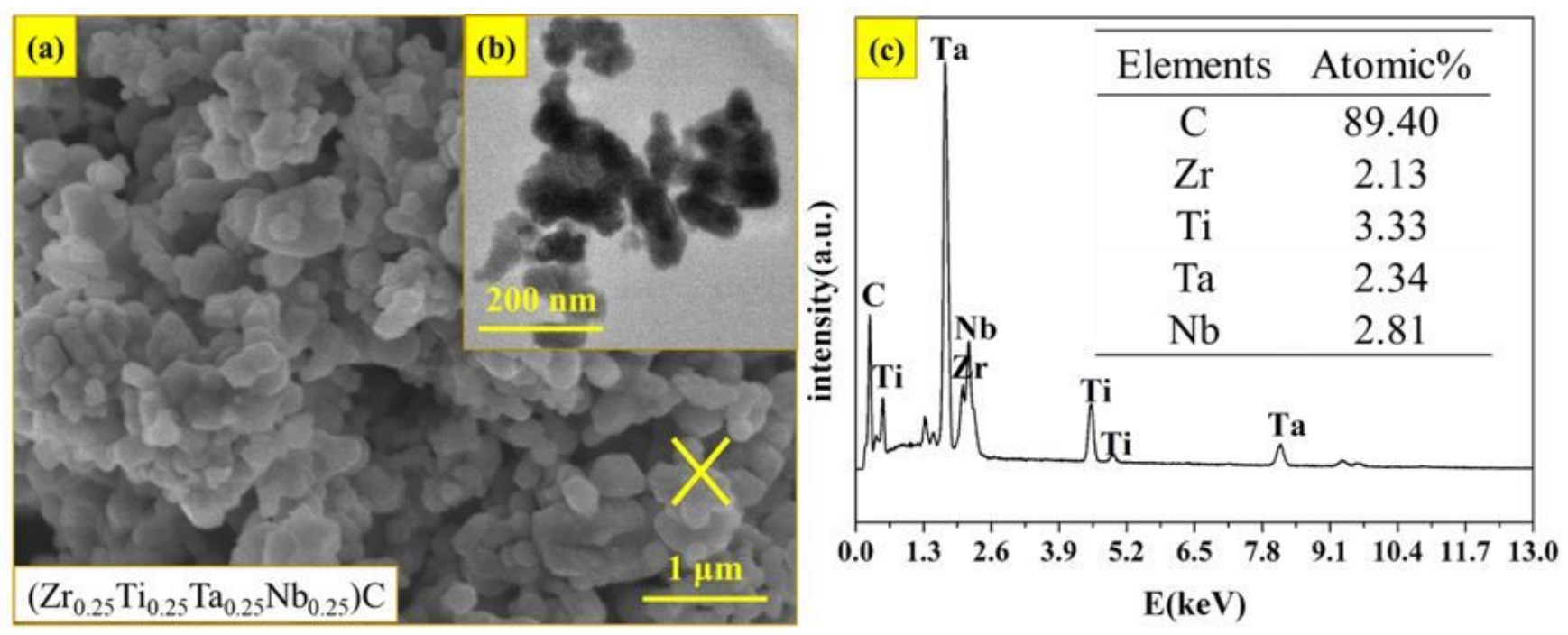

Figure 3

(a) SEM and (b) TEM images of ( $Z \mathrm{r} 0.25 \mathrm{Ti} 0.25 \mathrm{Ta} 0.25 \mathrm{Nb} 0.25) \mathrm{C}$ powders with an excess $5 \% \mathrm{C}$ heated at $1550 \mathrm{Q}$, and (c) EDS analysis of the region in (a) marked by yellow cross. 


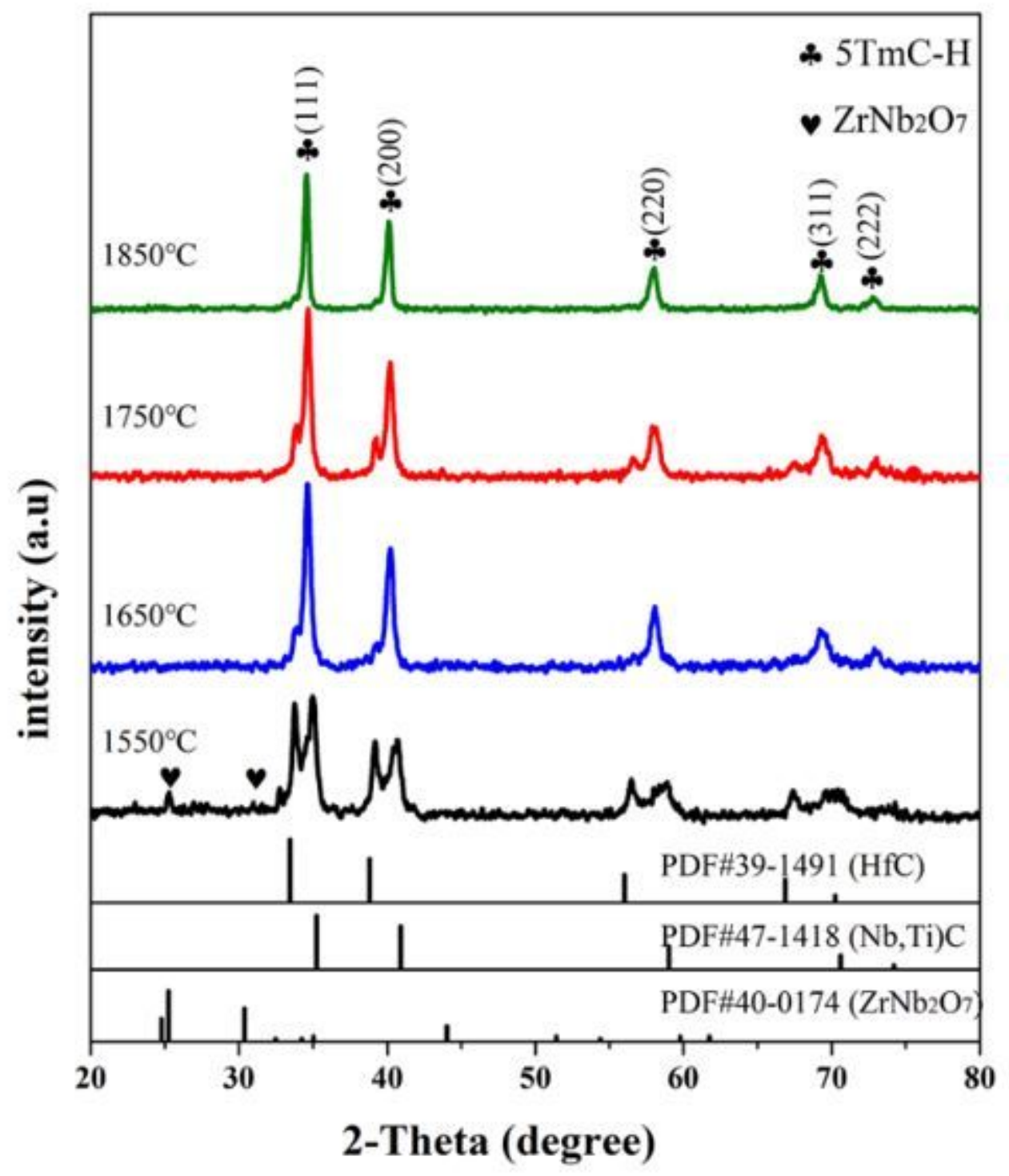

Figure 4

The XRD patterns of (Zr0.2Ti0.2Ta0.2Nb0.2Hf0.2) C samples after heat treatment at $1550{ }^{\circ} \mathrm{C}, 1650{ }^{\circ} \mathrm{C}$, $1750^{\circ} \mathrm{C}$ and $1850^{\circ} \mathrm{C}$, respectively.
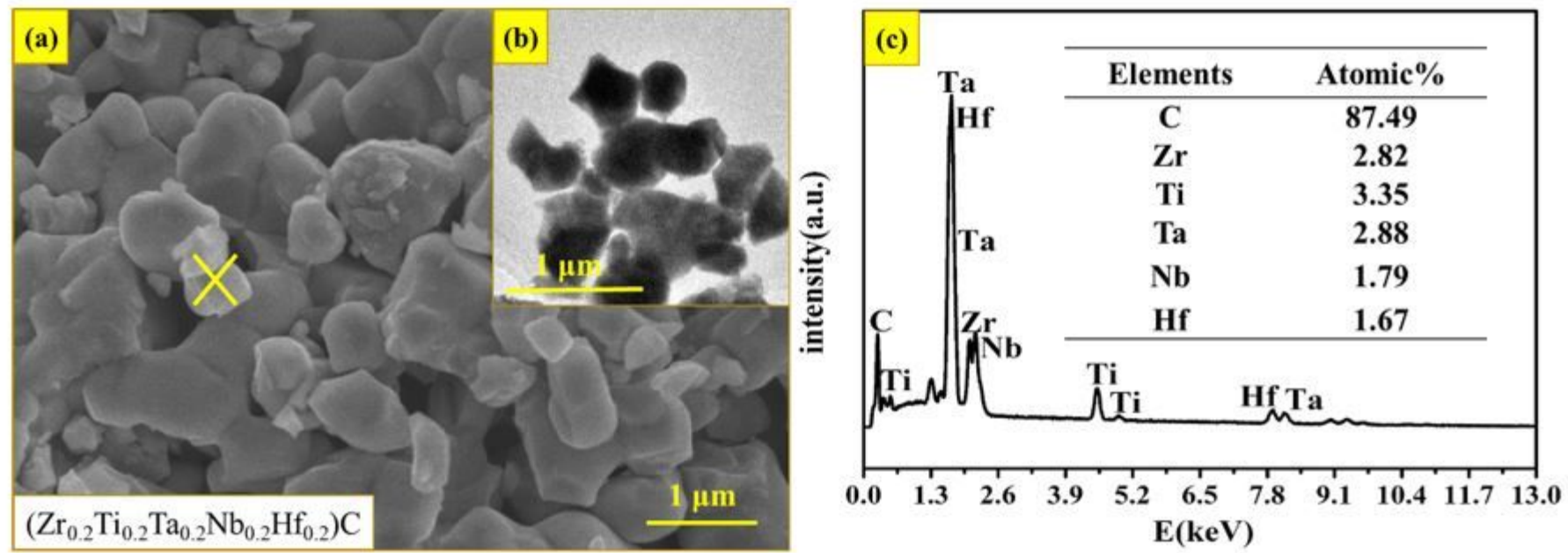
Figure 5

(a) SEM and (b) TEM images of (Zr0.2Ti0.2Ta0.2Nb0.2Hf0.2)C powders annealed at $1850 \mathrm{Q}$, and (b) EDS point analysis of the region in (a) marked by yellow cross.

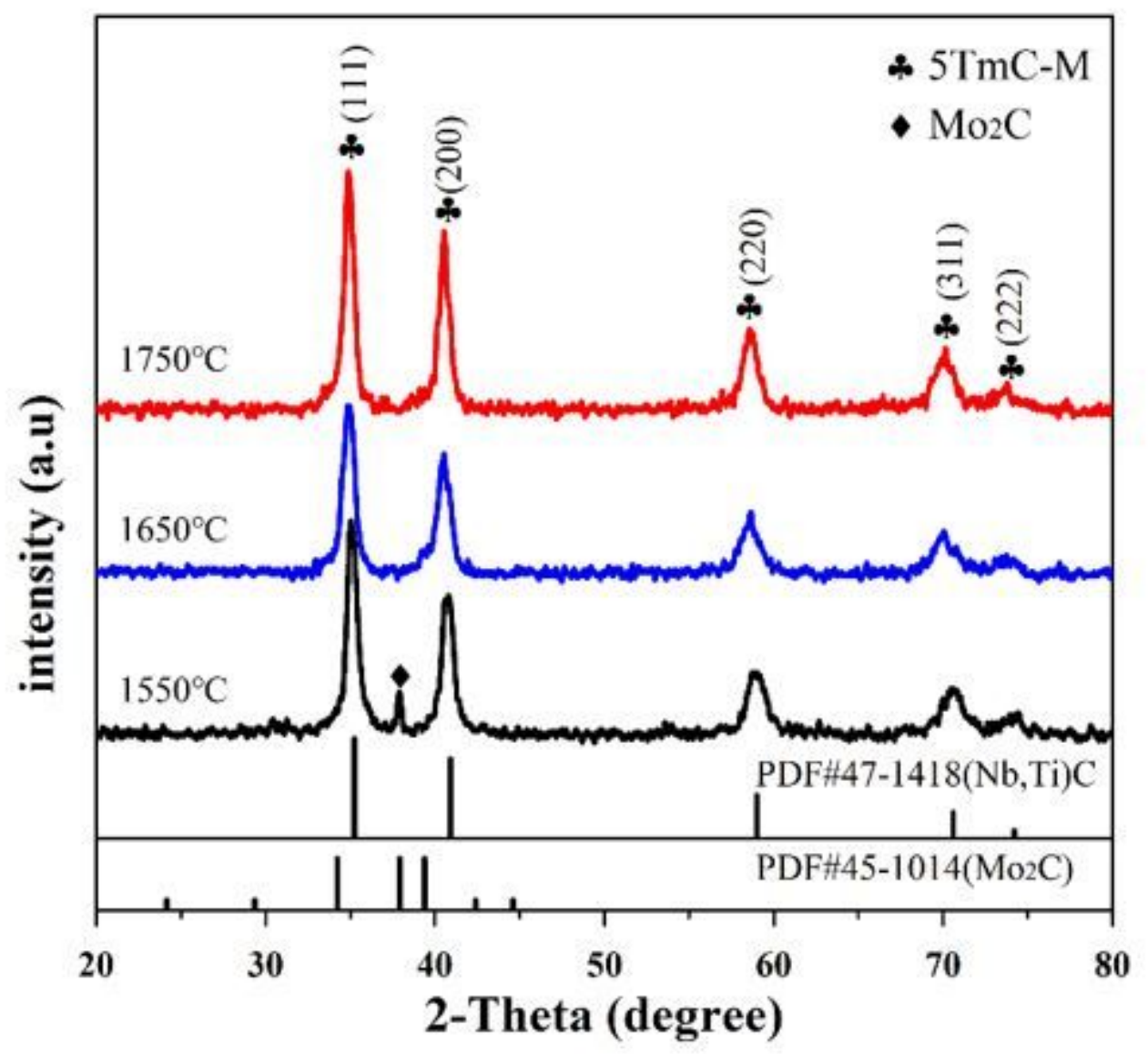

Figure 6

The XRD patterns of (Zr0.2Ti0.2Ta0.2Nb0.2Mo0.2) C samples after heat treatment at $1550{ }^{\circ} \mathrm{C}, 1650{ }^{\circ} \mathrm{C}$ and $1750^{\circ} \mathrm{C}$, respectively. 

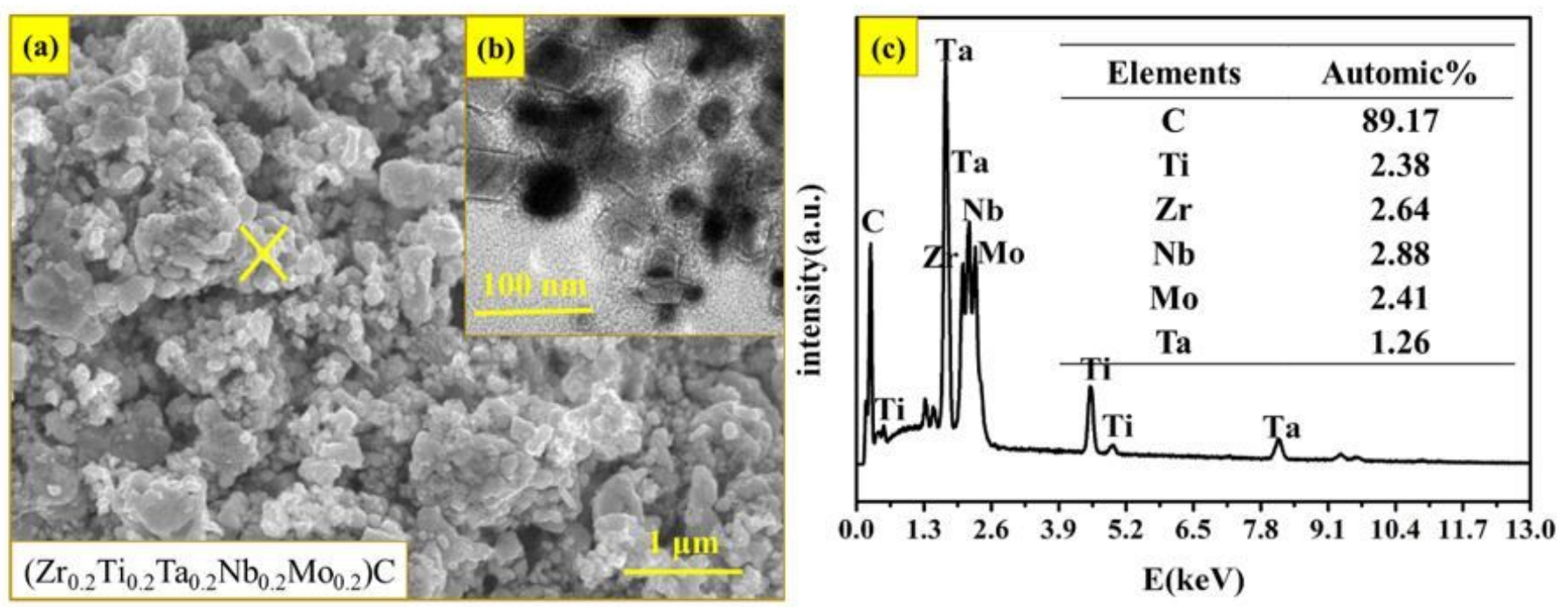

Figure 7

(a) SEM and (b) TEM images of (Zr0.2Ti0.2Ta0.2Nb0.2Mo0.2) C powders annealed at $1750{ }^{\circ} \mathrm{C}$, and (c) EDS point analysis of the region in (a) marked by yellow cross.

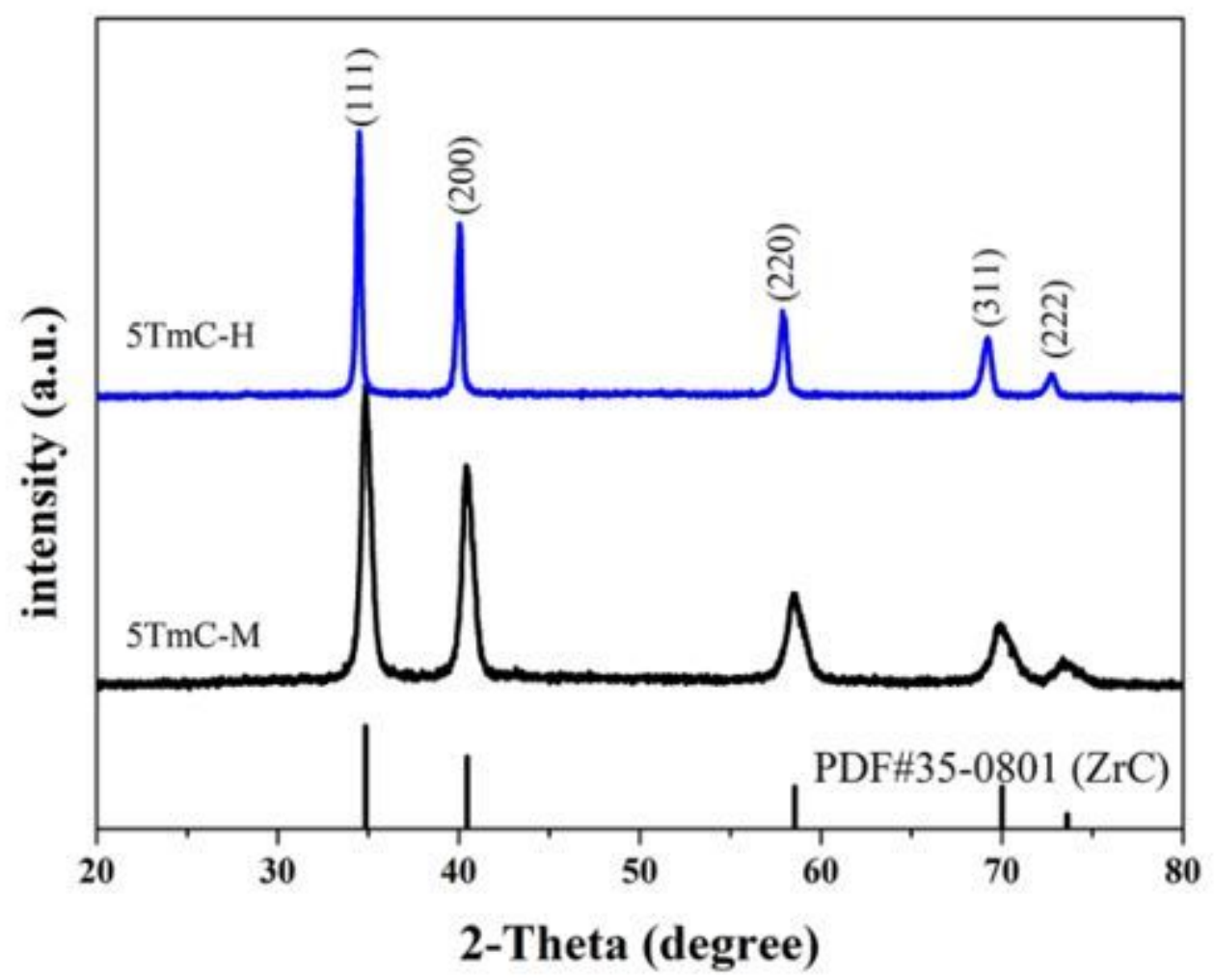

Figure 8

The XRD of single phase (ZrO.2Ti0.2Ta0.2Nb0.2Hf0.2) C and (Zr0.2Ti0.2Ta0.2Nb0.2Mo0.2) C heated treated at $1550 \mathrm{Q}$ in argon atmosphere for $5 \mathrm{~h}$. 